\title{
PENGARUH AKTIVITAS SISWA DALAM BEROLAHRAGA SELAMA MASA PANDEMI TERHADAP KEMAMPUAN SISWA DALAM BERBAHASA ARAB
}

\author{
Nurul Hidayah $^{1}$ \& Arif Setiawan ${ }^{2}$ \\ ${ }^{1}$ Universitas Islam Negeri Raden Fatah Palembang \\ ${ }^{2}$ Sekolah Islam Terpadu Insan Mandiri Cendikia Palembang
}

\begin{tabular}{ll}
\hline Keyword & Abstrac \\
\hline Education & Covid 19 has made students do not have activities outside the \\
Sport & home, so students spend more time in front of the screen than \\
Arabic & activities. The lack of activity not only makes students unhealthy \\
Activity & but also weakens their academic achievement because it focuses \\
Pandemy & more on playing gadgets. This research method is a survey \\
Corresponding Author & method to see the influence of both variables. This research shows \\
Nurul Hidayah & in Arabic. This is because an active Student will maximize his \\
UIN Raden Fatah & senses to explore the outside world thus making him able to \\
Indonesia & complete complex learning tasks and support cognitive and \\
nurulhidayah@radenfat & language development. Students who have high activity in \\
ah.ac.id & exercising are fitter and stronger while children who learn \\
languages from elementary school age are able to make their & brains receive more vocabulary. So that these two variables not \\
only affect each other as much as 87.7 o but also support each \\
other to make children smarter and healthier
\end{tabular}

\begin{abstract}
Abstrak
Covid 19 membuat siswa tidak memiliki aktivitas di luar rumah, sehingga siswa lebih banyak menghabiskan waktu di depan layar daripada aktivitas. Kurangnya aktivitas tidak hanya membuat siswa tidak sehat tetapi juga melemahkan prestasi akademik mereka karena lebih fokus pada bermain gadget. Metode penelitian ini merupakan metode survei untuk melihat pengaruh kedua variabel tersebut. Penelitian ini menunjukkan bahwa anak yang memiliki aktivitas tinggi dalam olahraga dapat memiliki kemampuan berbahasa Arab yang baik. Hal ini dikarenakan Siswa yang aktif akan memaksimalkan indranya untuk menjelajahi dunia luar sehingga membuatnya mampu menyelesaikan tugas-tugas belajar yang kompleks dan mendukung perkembangan kognitif dan bahasa. Siswa yang memiliki aktivitas tinggi dalam berolahraga lebih bugar dan kuat sedangkan anak yang belajar bahasa sejak usia sekolah dasar mampu membuat otaknya menerima lebih banyak kosakata. Sehingga kedua variabel tersebut tidak hanya saling mempengaruhi sebesar $87,7 \%$ tetapi juga saling mendukung untuk menjadikan anak lebih pintar dan sehat.
\end{abstract}

Kata Kunci: Pendidikan, Olahraga, Arab, Aktivitas, pandemi 


\section{PENDAHULUAN}

Sejak tahun 2020 Indonesia dihebohkan dengan kedatangan virus covid 19. Kedatangan virus ini tentu saja membuat kehidupan yang dijalani oleh rakyat Indonesia sangat berbeda, yang pada awalnya bebas ke berbagai tempat, namun saat ini pemerintah terus membuat peraturan yang membuat setiap lini kehidupan terkurung dalam dunia maya termasuk pendidikan, hal ini tentu saja adalah sebagai upaya untuk pencegahan agar penyebaran virus ini dapat dihambat.

Kini sudah tiga semester siswa dari Play group hingga Sekolah Menengah Atas mengikuti pembelajaran daring. Tentunya hal ini adalah hal yang harus difikirkan secara seksama, karena banyaknya keluhan dari masyarakat yakni para Ibu tentang dampak negative pembelajaran daring. Penelitian Arif dan Deni menunjukkan bahwa penggunaan gadget yang tidak terkontrol selama masa pandemic ini telah membuat siswa mengalami kecanduan gadget (Widodo \& Sutisna, n.d.).

Purwanto juga melihat hal tersebut sebagai bentuk kebosanan anak dalam belajar dan kurangnya intervensi orang tua dalam pembelajaran, sehingga anak sering merasa bosan dan terkurung dalam aktivitas yang sama setiap harinya, tanpa ada interaksi dengan teman sebayanya ataupun guru yang sedang mengajar (Purwanto et al., 2020) .

Kurangnya intervensi orang tua dalam pembelajaran berdampak pada kurang terarahnya pembelajaran, apalagi jika pembelajaran bersifat teoritis dan mewajibkan siswa untuk duduk dan berfikir serta menjalin komunikasi dua arah dengan gurunya. Padahal jika dilihat dari usianya, Anak usia SD senang bermain dan bergerak.

Anak yang tidak diberikan kesempatan untuk bergerak dan melakukan aktivitas menyenangkan seperti bermain akan berdampak pada pertumbuhan fisik dan emosi yang kurang optimal. Sedangkan pada usia sekolah dasar adalah usia terbaik anak untuk terus bereksplorasi dan berkembang jika siswa terus dibimbing menjadi siswa aktif secara fisik dan belajar sesuai keterampilan (Burhaein, 2017)

Keterampilan yang dipelajari oleh siswa yang aktif tentunya akan berbeda dibandingkan dengan keterampilan anak yang tidak aktif. Aktif di dalam penelitian ini dibatasi dengan memiliki kegiatan atau aktivitas. Selama masa pembelajaran luring siswa aktif dimaknai dengan siswa yang sering melakukan interaksi baik dengan guru ataupun dengan teman sebayanya selama pembelajaran. Namun kata aktif dalam pembelajaran selama masa pandemic nampaknya masih sulit untuk dilihat secara langsung di dalam proses belajar karena adanya beberapa kendala seperti sinyal dan kecanggihan dari gawai yang digunakan oleh guru dan siswa serta masih banyak yang lain.

Masa pandemic juga tidak boleh mengambil hak anak untuk memiliki setidaknya 5 kemampuan dasar yang akan berkembang ketika masa kanak-kanak, diantaranya adalah gerak kasar, gerak halus, berbicara/berbahasa, bersosialisasi dan kemandirian (Rubiyatno, 2014), karena ke lima kemampuan ini lah yang akan menjadi pondasi anak untuk mengeksplorasi lebih banyak terkait dunianya. Selain itu saat berusia 6 tahun sampai masa pubertas bagian otak yang disebut dengan lobus temporal dan lobus parietal tumbuh sangat signifikan, sehingga terjadi lonjakan perubahan terhadap kemampuan anak, dimulai dengan meningkatnya kekuatan otot, pengendalian motoric dan juga perkembangan kognitif (Arnidha, 2020). Berbekal hal tersebut masa ini tentunya dianggap mampu membuat anak belajar lebih banyak

Bahasa sebagai salah satu system kognitif anak (Sa'ida, 2018), pertumbuhan intelektual (kognitif) dapat dirangsang melalui gerakan-gerakan sederhana, karena koordinasi gerak yang miskin mengakibatkan lambatnya pertumbuhan intelektual (kognitif). Selain itu juga anak dapat mengekspresikan diri melalui gerakan dan berpikir melalui gerak tubuh. (Sasi, 2011). Mengacu pada teori tersebut dapat diasumsikan bahwa melalui kemampuan gerak dasar, kognitif anak dapat ditingkatkan

Cendana dan Suryana mencoba membuat siswa aktif dengan pengoptimal permainan tradisional yang mana permainan ini melibatkan aktivitas fisik, aktivitas ini akan membuat anak meningkatkan kemampuannya dalam mendengar, meniru kembali 3-4 
kata, mengerti beberapa perintah yang diberikan bersamaan ng diberikan bersamaan, memahami permainan yang akan dimainkan, mengenal perbedaan kata mengenai kata sifat, menirukan kalimat yang disampaikan secara sederhana, menjawab pertanyaan, mengutarakan pendapat kepada orang lain, menceritakan kembali permainan yang telah dimainkan secara sederhana, mengenal suara-suara yang ada disekitarnya (Cendana \& Suryana, 2022)

Dari uraian diatas dapat disimpulkan bahwasanya anak usia sekolah dasar sebaiknya dibina sejak dini untuk senantiasa beraktivitas karena aktivitas tersebut sangat berdampak pada tumbuh kembang yang akan dialami oleh siswa tersebut. Penelitian sebelumnya belum mengulas secara eksplisit terkait dampak langsung dari aktivtas yang dilakukan siswa, oleh karena itu penelitian ini mencoba untuk menguraikan secara mendalam terkait pengaruh aktivitas olahraga terhadap kemampuan siswa dalam berbahasa arab

\section{METODE}

Metode yang digunakan dalam penelitian ini adalah metode survey dengan tujuan untuk melihat adakah pengaruh yang postitif dan signifikan aktivitas olahraga terhadap kemampuan siswa dalam berbahasa Arab. Adapun pendekatan yang digunakan adalah pendekatan kuantitatif dengan mengumpulkan data kuantitatif baik aktivitas olahraga dan kemampuan siswa dalam berbahasa arab

Dalam penelitian ini terdapat dua variable penelitian yaitu aktivitas olahraga dan kemampuan berbahasa arab. Aktivitas olahraga adalah nilai yang diperoleh siswa selama satu semester, adapun nilai ini diperoleh tidak hanya melalui nilai yang bersifat tertulis, tapi juga akumulasi dari nilai praktik selama pembelajaran. Adapun kemampuan berbahasa arab adalah kemampuan siswa dalam berbahasa arab yang dalam hal ini berbentuk nilai akhir dari akumulasi hafalan kosa kata, praktik berbicara, pemahaman kaidah sederhanda dan penggabungan beberapa kata yang disusun menjadi sebuah kalimat yang sempurna.

Pelaksanaan penilitian ini berlangsung ketika semester ganjil tahun ajaran 2020/2021. Adapun yang menjadi populasi dalam penelitian ini adalah siswa sekolah insan mandiri cendikia Palembang yang ketika penelitian ini berlangsung sedang melakukan pembelajaran daring sebagaimana siswa di sekolah lainnya.

Metode pengumpulan data dalam penelitian ini adalah menggunakan dokumentasi nilai yang diperoleh siswa selama semester genap tahun ajaran 2020/202. Setelah data kuantitatif tersebut dikumpulkan maka selanjutnya peneliti melakukan uji normalitas, uji homogenitas, uji korelasi, dan uji regresi dengan menggunakan software spss 22.

\section{HASIL}

Penelitian ini memiliki dua variable yaitu variable aktivitas dan variable kemampuan berbahasa, keduanya merupakan data kuantitatif yang diambil untuk kemudian dianalisis menggunakan bantuan software SPSS, adapun deskripsi dari kedua variable tersebut adalah sebagai berikut:

Tabel 1. Descriptive Statistics

\begin{tabular}{|c|c|c|c|c|c|c|c|}
\hline & $\mathrm{N}$ & $\begin{array}{c}\text { Minimu } \\
\mathrm{m}\end{array}$ & $\begin{array}{c}\text { Maximu } \\
\mathrm{m}\end{array}$ & Mean & $\begin{array}{c}\text { Std. } \\
\text { Deviation }\end{array}$ & \multicolumn{2}{|c|}{ Kurtosis } \\
\hline & Statistic & Statistic & Statistic & Statistic & Statistic & Statistic & $\begin{array}{l}\text { Std. } \\
\text { Error }\end{array}$ \\
\hline Aktivitas Olahraga & 20 & 70 & 87 & 80.90 & 3.567 & 4.147 & .992 \\
\hline $\begin{array}{l}\text { Kemampuan Berbahasa } \\
\text { Arab }\end{array}$ & 20 & 71 & 88 & 81.70 & 3.962 & 1.719 & .992 \\
\hline Valid N (listwise) & 20 & & & & & & \\
\hline
\end{tabular}


Dari table di atas, dapat dilihat bahwasanya mean pada kemampun berbahasa Arab lebih tinggi dibandingkan dengan mean aktivitas olahraga yaitu sebesar 81,7 hal ini menunjukkan bahwa kemampuan siswa dalam berbahasa Arab sudah cukup baik Karena berada diatas nilai 80 begitu pula dengan aktivitas olahraga, walauupun dalam hal ini aktivitas olahraga memiliki mean 80,9.

Selanjutnya adalah analisis korelasi,

Tabel 2: Correlations

\begin{tabular}{llrr}
\hline & & $\begin{array}{c}\text { Kemampuan } \\
\text { Berbahasa Arab }\end{array}$ & $\begin{array}{c}\text { Aktivitas } \\
\text { Olahraga }\end{array}$ \\
\hline Kemampuan Berbahasa & Pearson Correlation & 1 & $.936^{* *}$ \\
Arab & Sig. (2-tailed) & & .000 \\
& $\mathrm{~N}$ & 20 & 20 \\
Aktivitas Olahraga & Pearson Correlation & $.936^{* *}$ & 1 \\
& Sig. (2-tailed) & .000 & \\
& $\mathrm{~N}$ & 20 & 20 \\
\hline
\end{tabular}

Dari table di atas, dapat dilihat bahwasanya kedua variable memiliki nilai signifikansi 0,000 yang menunjukkan bahwasanya kedua variable ini memiliki korelasi yang signifikan. Dilihat dari hasil Korelasi Pearson, diperoleh nilai 0,936 yang menunjukkan bahwa hasil dari korelasi ini sangat tinggi Karena memiliki korelasi maka proses analisis ini dilanjutkan dengan uji regresi

Tabel 3: regresi

\begin{tabular}{|c|c|c|c|c|c|c|}
\hline \multirow[b]{2}{*}{ Model } & \multirow[b]{2}{*}{$\mathrm{R}$} & \multirow[b]{2}{*}{ R Square } & \multirow[b]{2}{*}{$\begin{array}{l}\text { Adjusted R } \\
\text { Square }\end{array}$} & \multirow[b]{2}{*}{$\begin{array}{l}\text { Std. Error of } \\
\text { the Estimate }\end{array}$} & \multicolumn{2}{|c|}{ Change Statistics } \\
\hline & & & & & $\begin{array}{l}\text { R Square } \\
\text { Change }\end{array}$ & F Change \\
\hline 1 & $.936^{\mathrm{a}}$ & .877 & .870 & 1.288 & .877 & 127.784 \\
\hline
\end{tabular}

Dari table di atas, dapat dilihat bahwasanya Aktivitas olahraga memiliki pengaruh sebesar 87,7\% terhadap kemampuan berbahasa Arab.

\section{PEMBAHASAN}

Berdasarkan hasil perhitungan yang tertera pada penjelasan di atas, maka aktivitas olahraga selama masa pandemi memiliki pengaruh yang positif dan signifikan terhadap kemampuan siswa SIT Insan Mandiri Cendikia dalam berbahasa arab hal ini sesuai dengan pernyataan Naili yang menyatakan bahwasanya Aktivitas olahraga yang terstruktur sesuai dengan usia perkembanganya akan mempengaruhi kemampuan kognitif siswa. Kemampuan kognitif tentunya sangat beragam, namun dalam sekolah ini yang mana nota bene merupakan sekolah dasar islam peneliti lebih memfokuskan pada kemampuan kognitif dari segi berbahasa(Sa'ida, 2018).

Hal ini juga sesuai dengan pernytaan Roni yang menyatakan bahwasaya semakin tingi kemampuan kognitif maka akan semakin tinggi pula kemampuan siswa dalam menerima dan memproses informasi yang ada(Juwantara, 2019). Tingginya kemampuan siswa dalam berbahasa arab adalah dampak dari gembiranya siswa ketika melakukan aktivitas olahraga, hal ini disebabkan karena mata kuliah olahraga berada sebelum mata pelajaran bahasa arab, sehingga selepas siswa melakukan aktivitas olahraga seperti melompat, berlari, siswa akan merasakan bugar dan ceria.

Keceriaan mereka tentunya tidak luput dari kemampuan kognitif yang tinggi tadi. Siswa yang aktif dalam mengikuti aktivitas dalam olahraga tadi akan memiliki kesiapan untuk menerima materi yang lebih kompleks dibanding siswa yang tidak sungguhsungguh dalam mengikuti aktivitas olahraga 


\section{SIMPULAN}

Dari penelitian ini dapat disimpulkan bahwasanya terdapat pengaruh aktivitas olahraga yang positif dan signifikan terhadap kemampuan siswa dalam berbahasa Arab di SIT Insan Mandiri Cendikia sebesar. Pendidikan olahraga tidak hanya mampu membuat siswa "bermain" dalam proses pembelajarannya, namun aktivitas tersebut dapat berefek jangka panjang jika direncanakan secara sistematis. Siswa yang aktiv dan tertarik untuk mengeksplorasi dunia luar serta ke luar dari zona aman yang ditempatinya akan memperoleh lebih banyak kesempatan untuk menyerap materi lebih banyak dengan tingkat kesulitan yang bervariasi dibandingkan anak yang tidak aktif.

\section{DAFTAR PUSTAKA}

Arnidha, N. Y. dan Y. (2020). Perkembangan Fisik masa kanak-kanak dan implikasinya dalam pembelajaran. 12.

Burhaein, E. (2017). Aktivitas Fisik Olahraga untuk Pertumbuhan dan Perkembangan Siswa SD. Indonesian Journal of Primary Education, 1(1), 51. https://doi.org/10.17509/ijpe.v1i1.7497

Cendana, H., \& Suryana, D. (2022). Pengembangan Permainan Tradisional untuk Meningkatkan Kemampuan Bahasa Anak Usia Dini. Jurnal Obsesi: Jurnal Pendidikan Anak Usia Dini, 6(2), 771-778. https://doi.org/10.31004/obsesi.v6i2.1516

Juwantara, R. A. (2019). Analisis Teori Perkembangan Kognitif Piaget pada Tahap Anak Usia Operasional Konkret 7-12 Tahun dalam Pembelajaran Matematika. Al-Adzka: Jurnal Ilmiah Pendidikan Guru Madrasah Ibtidaiyah, 9(1), 27. https://doi.org/10.18592/aladzkapgmi.v9i1.3011

Purwanto, A., Pramono, R., Asbari, M., Santoso, P. B., Wijayanti, L. M., Choi, C. H., \& Putri, R. S. (2020). Studi Eksploratif Dampak Pandemi COVID-19 Terhadap Proses Pembelajaran Online di Sekolah Dasar. EduPsyCouns: Journal of Education, Psychology and Counseling, 2(1), 1-12. Retrieved from https://ummaspul.ejournal.id/Edupsycouns/article/view/397

Rubiyatno, R. (2014). Peranan Aktivitas Olahraga Bagi Tumbuh Kembang Anak. Jurnal Pendidikan Olahraga, 3(88), 54-64.

Sa'ida, N. (2018). Bahasa Sebagai Salah Satu Sistem Kognitif Anak Usia Dini. Pedagogi : Jurnal Anak Usia Dini Dan Pendidikan Anak Usia Dini, 4(2), 16. https://doi.org/10.30651/pedagogi.v4i2.1937

Sasi, D. N. (2011). Meningkatkan Kemampuan Gerak Dasar dan Kognitif Anak Melalui Senam Irama. Jurnal Pnelitian Pendidikan, Edisi Khus(2), 46-52.

Widodo, A., \& Sutisna, D. (n.d.). Fenomena Gadget Addicted Pada Anak Usia Sekolah Dasar Selama Studi From Home. 7(1), 36-45. 